\title{
17: $18890997-18865810$
}

National Cancer Institute

\section{Source}

National Cancer Institute. 17: 18890997-18865810. NCI Thesaurus. Code C42421.

Physical location of GRAP_Gene 